\title{
THEORETICAL INVESTIGATIONS OF TOXIC COMPONENTS FORMATION IN A DUAL-FUEL LOW-EMISSION GAS TURBINE COMBUSTOR WHILE OPERATING ON GASEOUS FUEL
}

\section{ТЕОРЕТИЧНІ ДОСЛІДЖЕННЯ УТВОРЕННЯ ТОКСИЧНИХ КОМПОНЕНТІВ У ДВОПАЛИВНІЙ НИЗЬКОЕМІСІЙНІЙ КАМЕРІ ЗГОРЯННЯ ГТД ПІД ЧАС РОБОТИ НА ГАЗОПОДІБНОМУ ПАЛИВІ}

\section{Badri T. Disamidze}

badri.diasamidze@nuos.edu.ua ORCID: 0000-0002-1627-9494
Б. Т. Діасамідзе, аспірант

Admiral Makarov National University of Shipbuilding, Mykolaiv

Національний університет кораблебудування імені адмірала Макарова, м. Миколаїв

\begin{abstract}
Purpose. The main aim of the research is to analyze the role of gaseous fuel supply modes in the channels of axial-radial swirlers of a dual fuel low-emission combustion chamber of a gas turbine engine with a capacity of $25 \mathrm{MW}$ on the temperature field and environmental characteristics, including: emission of nitrogen oxide, carbon monoxide at different power rated mode.

Method. To increase the efficiency of processes in a dual-fuel gas turbine combustor, it is proposed to use the idea of preliminary mixing of hydrocarbon fuel with air in axial-radial swirlers. The formation of toxic components was investigated by means of computational hydrodynamics (CFD) tools for various modes of gaseous fuel supply for low-emission gas turbine combustion chamber with 16 fire tubes at different power rated mode. The main inlet parameters are: air flow rate $4.355 \mathrm{~kg} / \mathrm{s}$, temperature $770 \mathrm{~K}$, pressure $2.0523 \mathrm{MPa}$. Three-dimensional mathematical modeling has been used as a method of research. A low-emission gas turbine combustor with pre-mixing of fuel and air was selected as a research object.

Results. An efficient method of organizing the working process in a dual-fuel gas turbine low-emission combustion chamber is proposed. Theoretical researches of influence of quantity of distribution of fuel through axial-radial swirlers on ecological parameters are carried out. 4 variants of calculation with different ratio of fuel distribution through internal and external swirlers are carried out. The choice of mathematical model of gaseous fuel combustion in dualfuel low-emission combustion chamber is made taking into consideration formation of the main toxic components.

Three-dimensional mathematical model of combustion of gaseous fuel in a dual-fuel low-emission combustion chamber running on gaseous fuels is based on the equations: continuity, conservation of momentum, conservation of energy, transfer of chemical components of the mixture, transfer of nitrogen oxides. Graphs of the dependence of volumetric concentrations of nitrogen oxide $\mathrm{NO}$, carbon monoxide $\mathrm{CO}$, and uneven temperature field on the ratio of gaseous fuel flow rates through the channels of axial-radial swirlers of the low-emission combustion chamber were carried out using three-dimensional mathematical modeling.

Scientific novelty. As result the knowledge about gaseous fuel combustion process in dual-fuel combustion chambers was deepened.

Practical importance. This work has been theoretical in nature; however, the obtained results could be used in the State Research and Development Production Gas Turbine Complex "Zorya" - "Mashproekt" when upgrading existing engines.
\end{abstract}

Key words: gas turbine engine; dual-fuel low-emission combustor; combustion process.

Анотація.

Мета. Метою роботи є дослідження впливу режимів подачі газоподібного палива в канали аксіально-радіальних завихрювачів низькоемісійної камери згоряння газотурбінного двигуна потужністю 25 МВт на температурне поле та екологічні характеристики, що містять в собі: емісію оксиду азоту, оксиду вуглецю під час роботи камери згоряння на режимі номінальної потужності.

Методика. Утворення токсичних компонентів досліджувалось за допомогою інструментів обчислювальної гідродинаміки (CFD) для варіанту низькоемісійної газотурбінної двопаливної камери згоряння з 16 жаровими 
трубами на номінальному режимі за витрати повітря 4,355 кг/с, температурі 770 К, тиску 2,0523 МПа. Розрахунки проводяться за допомогою тривимірного математичного моделювання.

Результати. Запропоновано ефективний спосіб організації робочого процесу в двопаливній газотурбінній низькоемісійній камері згоряння. Проведені теоретичні дослідження впливу розподілу палива через відцентрові завихрювачі на екологічні показники. Проведено 4 варіанта розрахунку з різним співвідношенням палива через внутрішній і зовнішній завихрювачі. Здійснено вибір математичної моделі вигоряння газоподібного палива в двопаливній низькоемісійній камері згоряння з урахуваннях утворення основних токсичних компонентів. Тривимірна математична модель вигоряння газоподібного палива в двопаливній низькоемісійній камері згоряння заснована на рівняннях: нерозривності, збереження кількості руху, збереження енергії, перенесення хімічних компонентів суміші, перенесення оксидів азоту.

За допомогою тривимірного математичного моделювання отримано графіки залежності об'ємних концентрацій: оксиду азоту NO, монооксиду вуглецю СО, нерівномірності температурного поля від співвідношень витрат газоподібного палива, що подається в канали аксіально-радіальних завихрювачів низькоемісійної камери згоряння ГТД.

Наукова новизна. Отримано нові знання щодо організації робочого процесу в двопаливних камерах згоряння ГТД під час роботи на газоподібному паливі.

Практична значимість. Ця робота має теоретичний характер, проте отримані результати можуть бути використані в ДП «Науково-виробничий комплекс газотурбобудування» «Зоря» - «Машпроєкт» під час модернізації існуючих двигунів.

Ключові слова: газотурбінний двигун; двопаливна низькоемісійна камера згоряння; процес горіння палив.

\section{ПОСТАНОВКА ПРОБЛЕМИ}

Підвищення ефективності процесів горіння органічних палив у турбінних агрегатах $є$ важливою технічною задачею, вирішення якої привносить результат одразу у декількох сферах: науково-технічній, екологічній, економічній.

Розробка перспективних конструкцій камер згоряння газотурбінних агрегатів та поглиблення розуміння процесів спалювання органічних палив в двохфазних потоках може привести до збільшення рівня конкурентоспроможності вітчизняних ГТД на світовому ринку.

У цій роботі розглядається двопаливна низькоемісійна камера згоряння ГТД, в якій організовується гомогенно-дифузійне горіння паливо-повітряної суміші, яке визначається як фізичними процесами сумішоутворення, так і кінетикою хімічних реакцій. Під час розробки моделі турбулентних хімічно реагуючих потоків в таких камерах враховано, що вона повинна містити ряд субмоделей найбільш важливих фізичних і хімічних процесів: сумішоутворення реагентів до повної молекулярної однорідності, турбулентного переносу, а також горіння газоподібного та рідкого палив з урахуванням пульсацій концентрацій компонентів реагуючої системи.

\section{АНАЛІЗ ОСТАННІХ ДОСЛІДЖЕНЬ І ПУБЛІКАЦІЙ}

Питання математичного моделювання в сучасних камер згоряння ГТД морського i наземного призначення розглянуто рядом авторів: S.B. Роре, B.E. Launder, D.B. Spalding, T. Echekki, E. Mastorakos, A.S. Newale, P. Pepiot, A.J. Aspden, M.S. Day [1-7]; створенню паливоспалюючих пристроїв приділено увагу С.І. Сербіним, С.В. Вілкулом, Г.Б. Мостіпаненко, І.Б. Матвєєвим, К.С. Бурунзус, О.К. Чередіченко,
М. Дзіда, Б.Т. Діасамідзе та інші [7-14]; застосування i ефективне споживання палива в ГТД як судової енергетичної установки розглянуто А.A. Banawan, M.M. El Gohary, I.S. Sadek [15-17]; методи стабілізації полум'я розглянуті С.I. Сербіним, К.С. Бурунзус, А.В. Козловським в роботах [18-20]. Запропонована дослідницька робота виконана $з$ урахуванням рекомендацій щодо моделювання горіння вуглеводневих палив у камері згоряння газотурбінного двигуна.

\section{ВІДОКРЕМЛЕННЯ НЕ ВИРІШЕНИХ РАНІШЕ ЧАСТИН ЗАГАЛЬНОЇ ПРОБЛЕМИ}

Проблема створення камер згоряння, що мають можливість працювати одночасно на декількох видах палива, $є$ актуальною з точки зору розвитку потужності турбінних двигунів та розширення діапазону їх практичного застосування.

Дослідження процесів горіння газоподібного палива в низькоемісйній двопаливній камері згоряння газотурбінного двигуна та утворення основних токсичних компонентів $\epsilon$ актуальним завданням.

Математичне моделювання турбулентного горіння в таких камерах - це спільне моделювання гідродинаміки та хімічної кінетики, а також взаємодії між турбулентним потоком і хімічними реакціями. При цьому точність прогнозування рівнів утворення шкідливих викидів значно залежить від точності опису полів швидкостей, тисків і температур.

\section{МЕТА РОБОТИ}

Метою роботи є дослідження впливу режимів подачі газоподібного палива в канали аксіально-радіальних завихрювачів низькоемісійної камери згоряння газотурбінного двигуна потужністю 25 МВт на температурне поле на виході 3 камери та емісію токсичних компонентів на режимі номінальної потужності. 


\section{ЕНЕРГЕТИЧНЕ МАШИНОБУДУВАННЯ № 1- 2021}

\section{МЕТОДИ, ОБ'СКТ ТА ПРЕДМЕТ ДОСЛІДЖЕННЯ}

Як метод дослідження обрано тривимірне числове моделювання із використанням моделей турбулентності, кінетичних механізмів окиснення вуглеводнів та утворення токсичних компонентів у хімічно реагуючих потоках.

Як об'єкт дослідження обрано процеси в низькоемісійній камері згоряння 3 попереднім перемішуванням паливо-повітряної суміші газотурбінного двигуна потужністю 25 МВт виробництва НВКГ «Зоря»-«Машроект»(м.Миколаїв)[9].Предметдослідження - фізико-хімічні закономірності процесів горіння газоподібного палива у двопаливній газотурбінній камері згоряння ГТД.

\section{ВИКЛАД ОСНОВНОГО МАТЕРІАЛУ}

Утворення токсичних компонентів досліджувалось за допомогою інструментів обчислювальної гідродинаміки (CFD) для варіанту низькоемісійної газотурбінної двопаливної камери згоряння з 16 жаровими трубами на номінальному режимі при витраті повітря 4,355 кг/с, температурі 770 К, тиску 2,0523 МПа.

Початкові дані для розрахунків низькоемісійної камери згоряння, що працює на газоподібному паливі, за різних режимів підведення палива представлено в табл. 1.

Математична модель двопаливної низькоемісійної камери згоряння, що працює на газоподібному паливі, заснована на рівняннях: нерозривності (1), збереження кількості руху (2), збереження енергії (3-4), перенесення хімічних компонентів суміші (5-8), перенесення оксидів азоту (9).

Рівняння збереження маси або рівняння нерозривності для стислих і нестислих середовищ запишемо у вигляді:

$$
\frac{\partial \rho}{\partial t}+\nabla(\rho \vec{u})=S_{m},
$$

де $\rho$ - густина робочого тіла;

$\vec{v}$ - вектор локальної швидкості потоку;

$S_{m}$ - джерельний член, який визначає масу, що вноситься в потік будь-яким способом.

Рівняння збереження кількості руху в нерухомій системі координат можна записати таким чином:

$$
\frac{\partial}{\partial t}(\rho \vec{v})+\nabla(\rho \vec{v} \vec{v})=\nabla p+\nabla(\overline{\bar{\tau}})+\rho \vec{g}+\vec{F},
$$

де $p$ - статичний тиск;

$\rho \vec{g}$ - гравітаційна сила, діюча на одиницю маси;

$\vec{F}$ - зовнішні сили, що діють на потік;

$\overline{\bar{\tau}}$ - тензор тисків.

Рівняння збереження енергії в загальному вигляді записується так:

$$
\frac{\partial}{\partial t}(\rho E)+\nabla(\overrightarrow{\mathrm{v}}(\rho E+p))=\nabla\left(-\vec{J}_{q}+\left(\overline{=}_{\text {eff }} \cdot \overrightarrow{\mathrm{v}}\right)\right)+S_{h},
$$

де $\vec{J}_{q}$ - густина теплового потоку суміші;

$\vec{J}_{j}$ - густина дифузійного теплового потоку $j$-го компонента суміші.

У рівнянні (3) повна енергія $E$ визначається таким чином:

$$
E=h-\frac{p}{\rho}+\frac{v^{2}}{2}
$$

де $h$ - ентальпія ідеального газу, що знаходиться за виразом $h=\sum_{j} Y_{j} h_{j}$ для багатокомпонентної суміші.

У цьому виразі $Y_{j}$ - концентрація $j$-го компоненту, а $h_{j}=\int_{T_{r f}}^{T} c_{p, j} d T$ - ентальпія компонента в інтервалі температур від $T_{\text {ref }}=293 \mathrm{~K}$ до температури $T$.

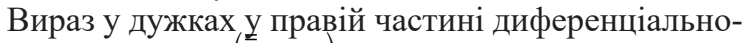
го рівняння (3) $-\left(\begin{array}{l}\underline{\tau} \text { eff } \\ \cdot \vec{v}\end{array}\right)$ описує в'язкісний нагрів. Оскільки для газів і хімічно реагуючих потоків внесок в'язкісного нагріву незначний, то рівняння збереження енергії можна перетворити таким чином :

$$
\frac{\partial}{\partial t}(\rho E)+\nabla(\vec{v}(\rho E+p))=-\nabla \vec{J}_{q}+S_{h},
$$

де $S_{h}=-\sum_{j} \frac{h_{j}^{0}}{M_{j}} R_{j}$ - джерельний член, що описує тепловиділення в результаті хімічних реакцій;

$h_{j}^{0}$ - ентальпія формування $j$-го компонента;

$R_{j}$ - об'ємна швидкість утворення компонента; $M_{j}$ - молярна маса.

Якщо необхідно враховувати рівняння для хімічних речовин, то отримати концентрацію кожного компонента можна розв'язавши рівняння для його кон-

\begin{tabular}{|c|c|c|c|c|}
\hline Назва параметру & \multicolumn{4}{|c|}{ Значення } \\
\hline Режим підведення палива & 1 & 2 & 3 & 4 \\
\hline Витрата метану через зовнішній завихрювач, кг/с & $\begin{array}{c}0,089 \\
(100 \%)\end{array}$ & $\begin{array}{c}0,07565 \\
(85 \%)\end{array}$ & $\begin{array}{l}0,0712 \\
(80 \%)\end{array}$ & $\begin{array}{c}0,06675 \\
(75 \%)\end{array}$ \\
\hline Витрата метану через внутрішній завихрювач, кг/с & 0 & $\begin{array}{c}0,01335 \\
(15 \%) \\
\end{array}$ & $\begin{array}{l}0,0178 \\
(20 \%)\end{array}$ & $\begin{array}{c}0,02225 \\
(25 \%) \\
\end{array}$ \\
\hline Витрата повітря через жарову трубу, кг/с & \multicolumn{4}{|c|}{4,35555} \\
\hline Тиск в камері, Па & \multicolumn{4}{|c|}{2052300} \\
\hline Температура повітря на вході в камеру, К & \multicolumn{4}{|c|}{770} \\
\hline Температура метану на вході в камеру, К & \multicolumn{4}{|c|}{309,6} \\
\hline
\end{tabular}
вективно-дифузійного переносу.

Рівняння збереження маси для окремих хімічних компонентів суміші у загальному вигляді має вигляд:

Таблиця 1. Вхідні параметри для розрахунку на номінальному режимі 


$$
\frac{\partial}{\partial t}\left(\rho Y_{i}\right)+\nabla\left(\rho \vec{u} Y_{i}\right)=-\nabla \vec{J}_{i}+R_{i}+S_{i}
$$

де $R_{i}$ - рівень утворення $i-$-го компоненту в результаті хімічної реакції;

$S_{i}$ - рівень додаткового утворення $i-$-го компоненту з дисперсної фази або інших джерел;

$\vec{J}_{i}$ - масова дифузія $i-$ го компоненту.

У цьому виді рівняння вирішується для $N-1$ компоненту, де $N$ - загальна кількість хімічних елементів, присутніх у системі.

Оскільки сумарна масова частка всіх компонентів повинна дорівнювати одиниці, то масова частка $N$-го компоненту визначається як одиниця мінус сума $N-1$ знайдених масових часток. Щоб звести до мінімуму числову помилку, $N$-й компонент вибирається таким чином, щоб його масова частка в суміші була максимальна. Цим компонентом може бути, наприклад $\mathrm{N}_{2}$, коли окиснювачем $є$ повітря.

Наступним кроком $\epsilon$ інтерпретація рівняння переносу хімічних компонентів в рівнянні збереження енергії. Для багатокомпонентних потоків перенесення ентальпії, яке здійснюється завдяки масовій дифузії

$$
\nabla\left[\sum_{i=1}^{n} h_{i} \cdot \vec{J}_{i}\right]
$$

може істотно впливати на розподіл ентальпії. Зокрема, коли число Льюїса:

$$
L e_{i}=\frac{\lambda}{\rho \cdot c_{p} \cdot D_{i, m}}
$$

для якого-небудь 3 компонентів значно відрізняється від одиниці, нехтування цією умовою може призвести до великих помилок. Відзначимо, що в рівнянні (6) $\lambda$ - коефіцієнт теплопровідності.

Для дифузійного режиму роботи двопаливних низькоемісійних камер згоряння газоподібне паливо досить швидко згоряє, і загальний рівень швидкості реакцій може визначатися турбулентним змішуванням. Тоді хімічною кінетикою під час моделювання можна знехтувати. Виходячи з цього, швидкість утворення $i$-го компонента $R_{i, r}$ в реакції $r$ можна знайти за меншим (лімітуючим) значенням двох наведених нижче виразів :

$$
\begin{aligned}
& R_{i, r}=v_{i, r}^{\prime} M_{\varpi, i} A \rho \frac{\varepsilon}{k} \min _{R}\left(\frac{Y_{R}}{v_{R, r}^{\prime} M_{\varpi, R}}\right), \\
& R_{i, r}=v_{i, r}^{\prime} M_{\varpi, i} A B \rho \frac{\varepsilon}{k} \cdot \frac{\sum_{p} p Y_{p}}{k \sum_{j}^{N} v_{j, r}^{\prime \prime} M_{\varpi, j}},
\end{aligned}
$$

де $Y_{p}$ - масова частка продукту реакції;

$Y_{R}$ - масова частка одного з реагентів;

$A=4$ - емпірична константа;

$B=0,5$ - емпірична константа.

У рівняннях (7) і (8) швидкість хімічної реакції визначається величиною тимчасового масштабу перемішування $\frac{k}{\varepsilon}$, де $k$ - кінетична енергія турбу-

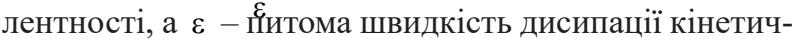

ної енергії турбулентності. Будемо вважати, що горіння відбувається скрізь, де присутня турбулентність, тобто $\frac{k}{c}>0$. Це припущення досить обгрунтовано для поперед дньо неперемішаних сумішей.

Математична модель емісії оксидів азоту являє собою систему рівнянь масового переносу, які враховують конвекцію, дифузію, а також утворення і розкладання NO і споріднених сполук та отримана на основі закону збереження маси. Вплив часу перебування реагентів у реакційному об'ємі на механізм утворення NOx враховано в конвективних членах визначальних рівнянь, записаних в Ейлеровій системі відліку. Для термічних і швидких оксидів азоту необхідно вирішувати рівняння переносу для NO, записане у векторній формі, засноване на рівнянні збереження маси для окремих хімічних компонентів суміші:

$$
\frac{\partial}{\partial t}\left(\rho Y_{\mathrm{NO}}\right)+\nabla\left(\rho \vec{v} Y_{\mathrm{NO}}\right)=\nabla\left(\rho D \nabla Y_{\mathrm{NO}}\right)+S_{\mathrm{NO}},
$$

де $Y_{\mathrm{NO}}-$ масова концентрація NO;

$D$ - коефіцієнт дифузіі;

$\vec{v}$ - вектор швидкості;

$S_{\mathrm{NO}}-$ джерельний член, який визначається в залежності від механізму утворення $\mathrm{NO}_{x}$.

Нижче представлено результати тривимірних розрахунків процесу горіння газоподібного палива в низькоемісійній газотурбінній камері згоряння на різних режимах подачі палива через завихрювачі. На рис. 1 показано поля температур в поздовжньому перерізі низькоемісійної камери згоряння ГТД для досліджених варіантів 1-4. Видно, що максимальні значення температур в поздовжньому переpiзi (2520 та 2560 К) характерні для варіантів 3 та 4. Зона високих температур простягається при цьому практично до вихідного перерізу жарової труби, що зумовлено неоптимальним співвідношенням окиснювач-паливо в центральній і приосьовій ії частині. У разі зменшення витрати газоподібного палива через канали внутрішнього завихрювача зростає коефіцієнт надлишку повітря в приосьовій області і, відповідно, падає температура продуктів згоряння. Так, для варіантів подачі палива 1 та 2 максимальна температура складає 1890 та 2140 К. Має місце більш рівномірний характер вигоряння пального по всьому об'ємі первинної зони жарової труби. Видно, що за наявності горіння в головній частині жарової труби утворюється потужна зона зворотних течій, в якій циркулюють продукти повного згоряння палива і спостерігаються максимальні температури.

Основна маса газоподібного пального хімічно реагує з киснем в первинній зоні жарової труби. Утворення оксидів азоту (рис. 2) залежить від величин температури та локального коефіцієнту надлишку повітря. Найвищі концентрації оксидів азоту та діоксиду вуглецю (рис. 3) мають місце в зонах максимальних температур в районі зони зворотних течій. 


\section{ЕНЕРГЕТИЧНЕ МАШИНОБУДУВАННЯ № 1 2021}

У зв'язку з більш високими температурами в об'ємі камери згоряння для варіантів 2-4 у порівнянні 3 першим варіантом спостерігаються більш високі пікові концентрації оксидів азоту NO у повздовжньому перерізі (рис. 3), а також й більш високі середньоінтегральні значення (у вихідному перерізі камери згоряння (рис. 4).

На рис. 4-6 представлено порівняння розподілу масових концентрацій оксиду азоту NO (в межах

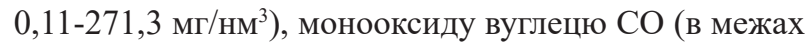

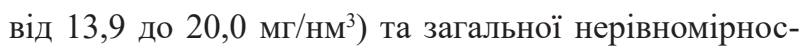
ті температури в вихідному перерізі жарової труби. Для першого варіанту нерівномірність поля температур у вихідному перерізі жарової труби камери згоряння дорівнює 16\% за максимальної температури 1666 K, мінімальної - 1360 K і середньо інтегральної1541 К. Цей показник є достатньо високим і може бути зменшений за допомогою оптимізації подачі палива в канали паливної форсунки та більш ефективного розподілу повітря за поясами охолодження.
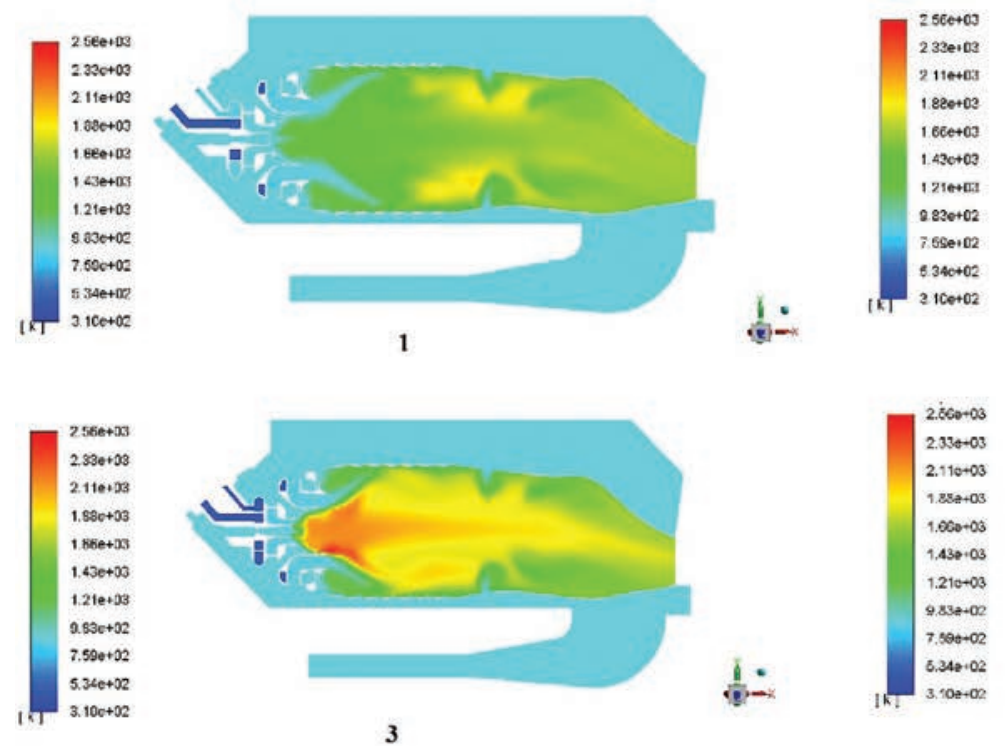

Рис. 1. Розподіл температур газу (К) повздовж жарової труби камери згоряння при різних режимах підведення газоподібного пального
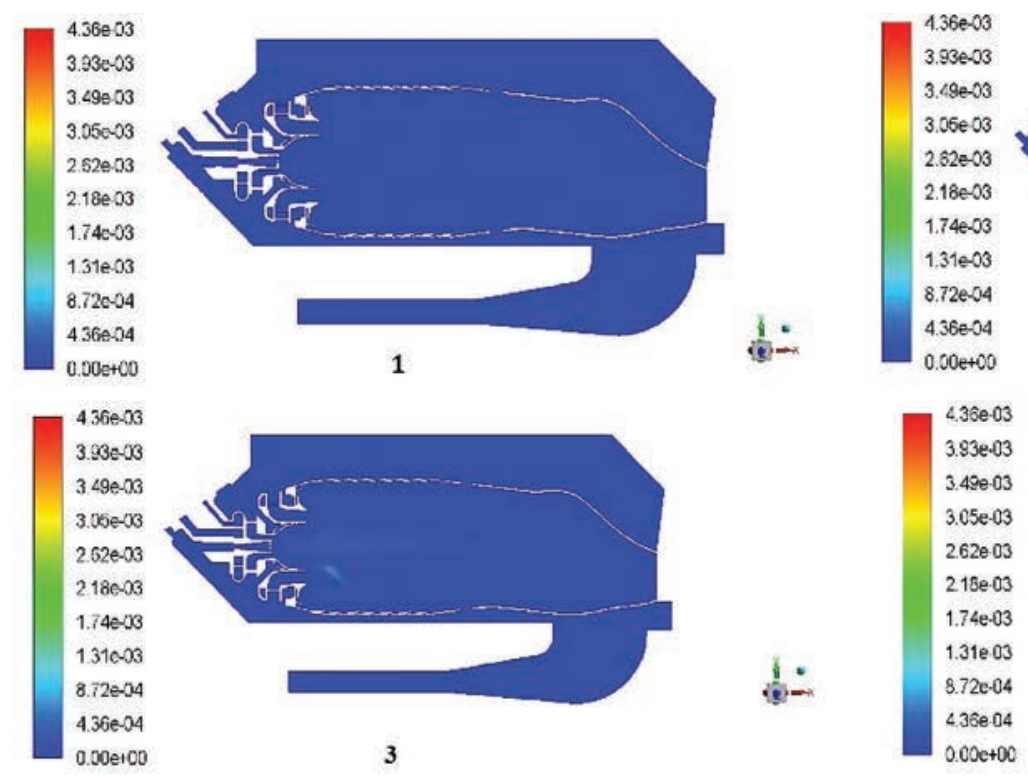

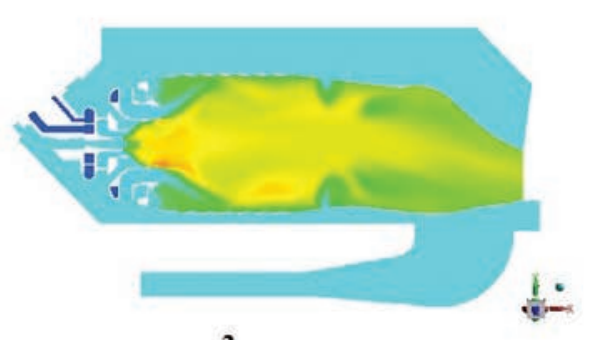

2

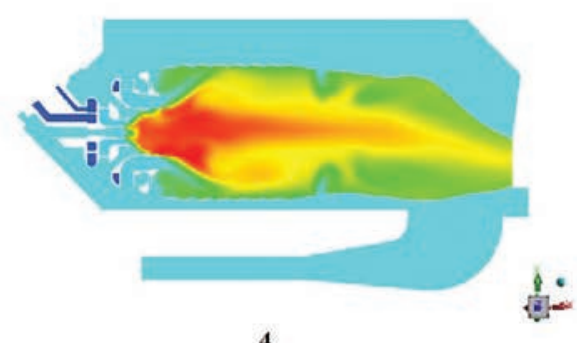


Параметри в вихідному перерізі жарової труби двопаливної низькоемісійної камери згоряння, що працює на газоподібному паливі, які характеризують iii екологічні показники для варіантів 1-4, представлено в табл. 2

\section{ОБГОВОРЕННЯ ОТРИМАНИХ РЕЗУЛЬТАТІВ}

Результати тривимірного математичного моделювання виявили залежність діапазону раціональних значень емісії токсичних елементів від способу підведення газоподібного палива. 3 точки зору екологічних характеристик найбільш прийнятним варіантом $€$ перший розглянутий варіант - зі 100\% підведенням паливного газу через зовнішній завихрювач на номінальному режимі. Однак слід зауважити, що під час підведення палива у кількості 100\% сумарної витрати пального через зовнішній завихрювач спостерігається нестабільна (з пульсаціями) робота камери згоряння, що може призвести до зриву полум'я. Тому для стабілізації процесу горіння пропонується декілька варіантів: 1) застосування плазмохімічної системи стабілізації [18-20]; 2) підведення незначної кількості газоподібного палива (до 15 \%) у внутрішній завихрювач.

Відмітимо, що застосування плазмохімічних систем та дослідження впливу низькотемпературної повітряної плазми на розподіл параметрів в двопаливній газотурбінній камері згоряння може розглядатися як предмет майбутніх досліджень.

\section{ВИСНОВКИ}

1. Проведено тривимірні розрахунки аеродинамічної структури потоку в двопаливній низькоемісій-
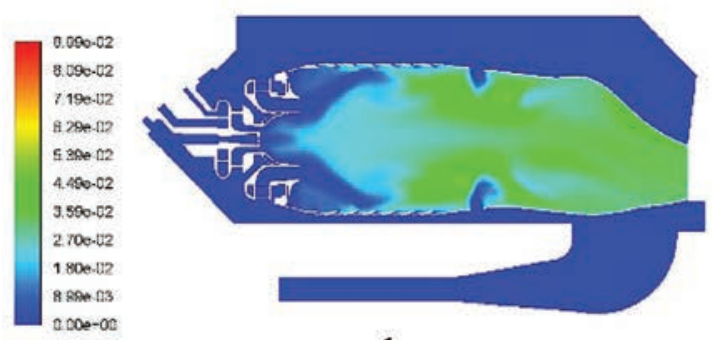

1
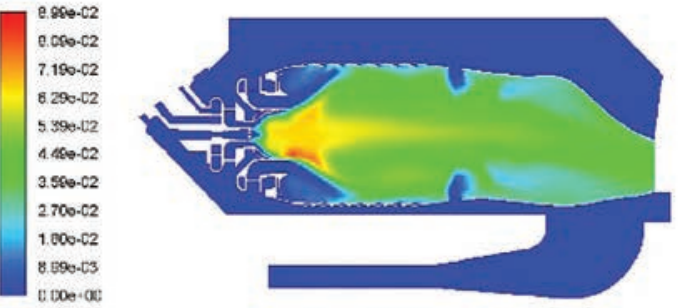

3
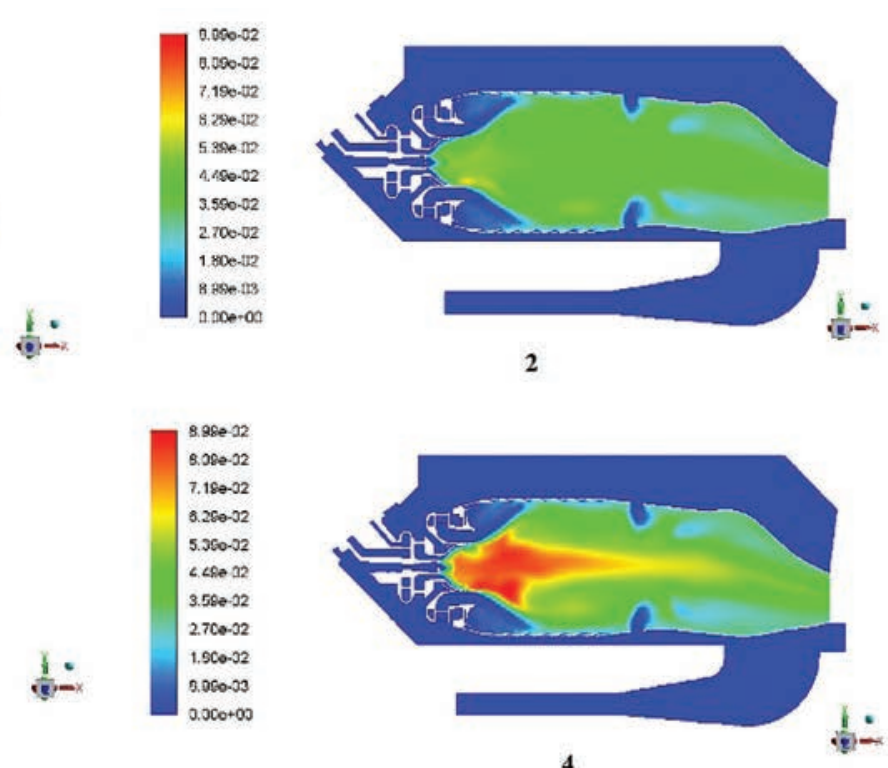

Рис. 3. Розподіл об’ємних концентрацій діоксиду вуглецю в жаровій трубі камери згоряння за різних режимів підведення газоподібного пального

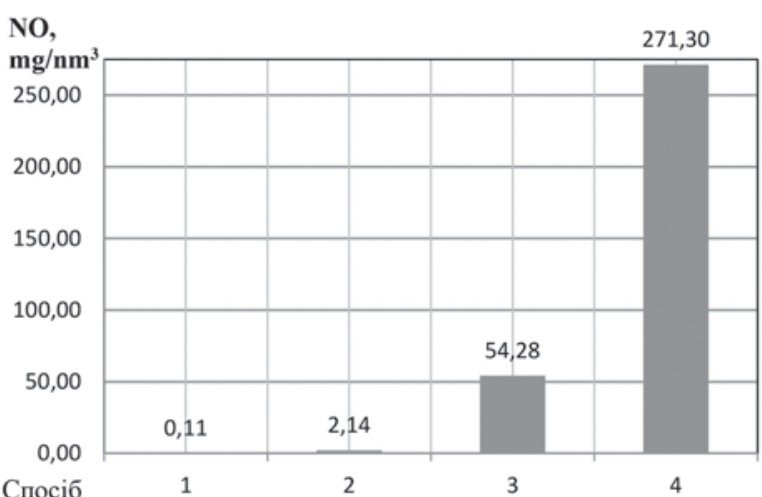

Рис. 4. Масові концентрації оксиду азоту NO в вихідному перерізі жарової труби для різних способів підведення палива

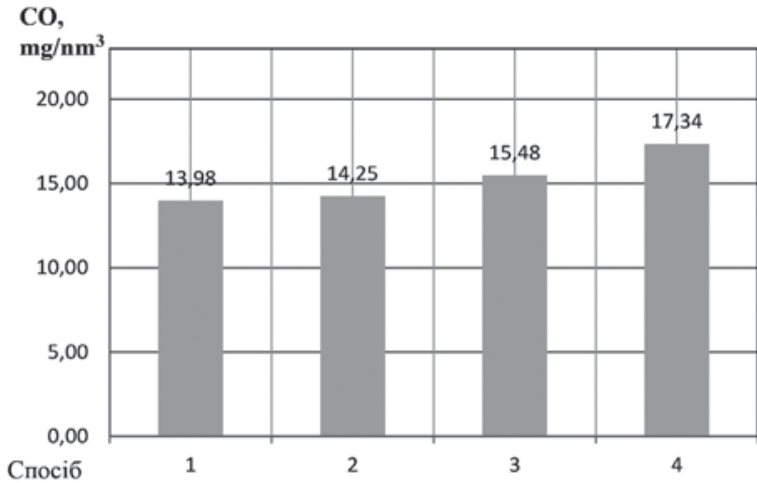

Рис. 5. Масові концентрації монооксиду вуглецю СО в вихідному перерізі жарової труби для різних способів підведення палива 


\section{ЕНЕРГЕТИЧНЕ МАШИНОБУДУВАННЯ № 1-2021}

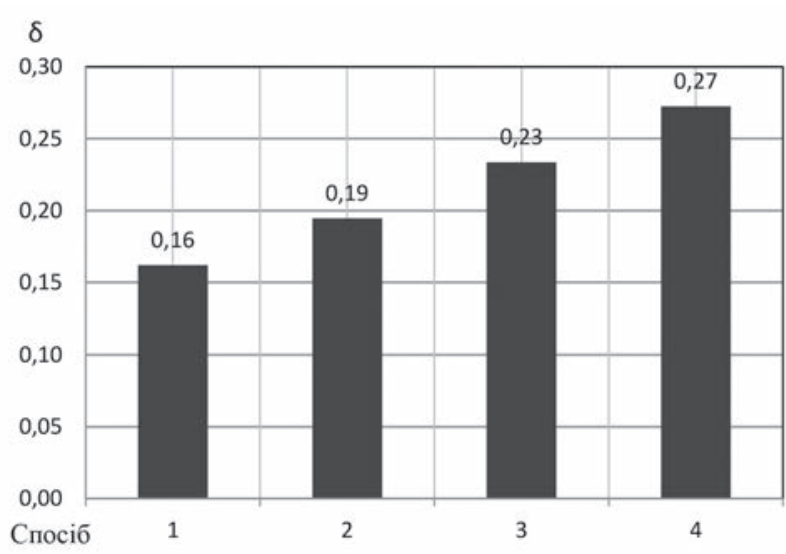

Рис. 6. Нерівномірність температурного поля в вихідному перерізі жарової труби за різних способів підведення палива

ній камері згоряння ГТД під час роботи на газоподібному паливі. Виявлено основні особисті формування зон зворотних течій в жаровій трубі камери згоряння на режимі номінальної потужності.

2. Отримано нові дані з розподілу температур, концентрацій продуктів повного згоряння і токсичних компонентів по перерізах двопаливної камери згоряння при тиску 2,05 МПа та підведенні газоподібного пального в різних співвідношеннях через канали внутрішнього і зовнішнього завихрювачів.

3. Найбільш раціональним 3 точки зору екологічних характеристик та нерівномірності температурного
Таблиця 2. Параметри на виході

3 камери згоряння

\begin{tabular}{|c|c|c|c|c|}
\hline Варіант & $\mathbf{1}$ & $\mathbf{2}$ & $\mathbf{3}$ & $\mathbf{4}$ \\
\hline Назва параметру & \multicolumn{4}{|c|}{ Значення } \\
\hline $\begin{array}{c}\text { 1. Середньомасова } \\
\text { температура, } \mathrm{K}\end{array}$ & 1544,60 & 1541,6 & 1540,9 & 1541,3 \\
\hline $\begin{array}{c}\text { 2. Мольна частка } \mathrm{CH}_{4}, \\
\text { ррт }\end{array}$ & $<0,01$ & $<0,01$ & $<0,01$ & $<0,01$ \\
\hline 3. Масова частка $\mathrm{CO}_{2}$ & 0,055 & 0,055 & 0,055 & 0,05524 \\
\hline 4. Масова частка $\mathrm{H}_{2} \mathrm{O}$ & 0,0452 & 0,0452 & 0,0451 & 0,0452 \\
\hline 5. Мольна частка $\mathrm{O}_{2}$ & 0,13 & 0,13 & 0,13 & 0,13 \\
\hline
\end{tabular}

поля на виході $є$ подача газоподібного палива у канали зовнішнього завихрювача в повному об’ємі. При цьому розрахункова емісія токсичних компонентів на виході жарової труби складає менше 5 ррт для оксидів азоту та менше 15 ppm для монооксиду вуглецю.

4. Визначена доцільність подальшої оптимізації робочого процесу в двопаливній камері згоряння 3 точки зору зменшення нерівномірності поля температур на виході жарової труби за рахунок удосконалення конструктивної схеми камери та перерозподілу кількості повітря, яке подається в зону горіння та на охолодження.

\section{REFERENCES}

[1] Pope, S.B. (2011). Simple models of turbulent flows. Physics of Fluids, 23(1), 011301.

[2] Launder, B.E., \& Spalding, D.B. (1972). Lectures in mathematical models of turbulence.

[3] Mador, R., \& Roberts, R. (1974, October). A pollutant emissions prediction model for gas turbine combustors. In 10th Propulsion Conference (p. 1113).

[4] Echekki, T., \& Mastorakos, E. (Eds.). (2010). Turbulent combustion modeling: Advances, new trends and perspectives (Vol. 95). Springer Science \& Business Media.

[5] Spalding, D.B. (2015). Numerical prediction of flow, heat transfer, turbulence and combustion. Elsevier.

[6] Newale, A.S., Pope, S.B., \& Pepiot, P. (2020). Computationally-efficient and accurate particle pdf simulations of turbulent combustion using coupled pre-partitioned adaptive chemistry and tabulation. Proceedings of the Combustion Institute.

[7] Aspden, A.J., Day, M.S., \& Bell, J.B. (2016). Three-dimensional direct numerical simulation of turbulent lean premixed methane combustion with detailed kinetics. Combustion and Flame, 166, 266-283.

[8] Serbin, S., Mostipanenko, A., Matveev, I. Investigation of the Working Processes in a Gas Turbine Combustor with Steam Injection. Proceedings of the ASME/JSME 8th Thermal Engineering Joint Conference AJTEC2011, USA 2011; AJTEC2011-44042:1-6

[9] Serbin, S., Mostipanenko, H. (2006).Chyslove modelyuvannya protsesiv horinnya v eksperymental'nomu vidsiku hibrydnoyi kamery z'horyannya HTD potuzhnistyu 25 MWt. Visnyk Natsional'noho tekhnichnoho universytetu "Kharkivs'kyy politekhnichnyy instytut». Zbirnyk naukovykh prats'. Tematychnyy vypusk: «Enerhetychni ta teplotekhnichni protsesy y ustatkuvannya», 5, 59-67. (Ukrainian)

[10] Diasamidze, B.T., Vilkul, S.V., \& Serbin, S.I. (2019). THEORETICAL INVESTIGATIONS OF A DUAL-FUEL LOW-EMISSION GAS TURBINE COMBUSTOR. Visnyk Natsional'noho tekhnichnoho universytetu "Kharkivs'kyy politekhnichnyy instytut». Zbirnyk naukovykh prats'. Tematychnyy vypusk: «Enerhetychni ta teplotekhnichni protsesy y ustatkuvannya»,1), 27-33. (Ukrainian)

[11] Serbin, S.I., Diasamidze B.T. (2019). INVESTIGATIONS OF LIQUID FUEL SPRAYING VELOCITY INFLUENCE ON CHARACTERISTICS OF A DUAL-FUEL GAS TURBINE COMBUSTOR. Zbirnyk naukovykh prats' NUOS, (1). (Ukrainian).

[12] Serbin, S., Burunsuz, K. (2020). Numerical study of the parameters of a gas turbine combustion chamber with steam injection operating on distillate fuel. International Journal of Turbo \& Jet-Engines, 1 (ahead-of-print).

[13] Serbin, S., Diasamidze, B., \& Dzida, M. (2020). Investigations of the working process in a dual-fuel low-emission combustion chamber for an FPSO gas turbine engine. Polish Maritime Research. 
[14] El-Gohary, M.M. (2012). The future of natural gas as a fuel in marine gas turbine for LNG carriers. Proceedings of the Institution of Mechanical Engineers, Part M: Journal of Engineering for the Maritime Environment, 226(4), 371-377.

[15] Cherednichenko, O., Serbin, S., \& Dzida, M. (2019). Investigation of the combustion processes in the gas turbine module of an FPSO operating on associated gas conversion products. Polish Maritime Research, 26(4), 149-156.

[16] Banawan, A.A., El Gohary, M.M., \& Sadek, I.S. (2010). Environmental and economical benefits of changing from marine diesel oil to natural-gas fuel for short-voyage high-power passenger ships. Proceedings of the Institution of Mechanical Engineers, Part M: Journal of Engineering for the Maritime Environment, 224(2), 103-113.

[17] El Gohary, M.M., \& Seddiek, I.S. (2013). Utilization of alternative marine fuels for gas turbine power plant onboard ships. International Journal of Naval Architecture and Ocean Engineering, 5(1), 21-32.

[18] Serbin, S., Kozlovskyi, A., \& Burunsuz, K. (2021). Influence of plasma-chemical products on process stability in a lowemission gas turbine combustion chamber. International Journal of Turbo \& Jet-Engines, 1 (ahead-of-print).

[19] Serbin, S.I. Modeling and Experimental Study of Operation Process in a Gas Turbine Combustor with a Plasma-Chemical Element. Combustion Science and Technology 1998; 139:137-158.

[20] Serbin, S.I., Kozlovskyi, A.V., Burunsuz, K.S. Investigations of non-stationary processes in low emissive gas turbine combustor with plasma assistance. IEEE Trans. Plasma Sci. 2016; 44(12):2960-2964.

\section{СПИСОК ВИКОРИСТАНОЇ ЛІТЕРАТУРИ}

[1] Pope, S.B. (2011). Simple models of turbulent flows. Physics of Fluids, 23(1), 011301.

[2] Launder, B.E., \& Spalding, D.B. (1972). Lectures in mathematical models of turbulence.

[3] Mador, R., \& Roberts, R. (1974, October). A pollutant emissions prediction model for gas turbine combustors. In 10th Propulsion Conference (p. 1113).

[4] Echekki, T., \& Mastorakos, E. (Eds.). (2010). Turbulent combustion modeling: Advances, new trends and perspectives (Vol. 95). Springer Science \& Business Media.

[5] Spalding, D.B. (2015). Numerical prediction of flow, heat transfer, turbulence and combustion. Elsevier.

[6] Newale, A.S., Pope, S.B., \& Pepiot, P. (2020). Computationally-efficient and accurate particle pdf simulations of turbulent combustion using coupled pre-partitioned adaptive chemistry and tabulation. Proceedings of the Combustion Institute.

[7] Aspden, A.J., Day, M.S., \& Bell, J.B. (2016). Three-dimensional direct numerical simulation of turbulent lean premixed methane combustion with detailed kinetics. Combustion and Flame, 166, 266-283.

[8] Serbin, S., Mostipanenko, A., Matveev, I. Investigation of the Working Processes in a Gas Turbine Combustor with Steam Injection. Proceedings of the ASME/JSME 8th Thermal Engineering Joint Conference AJTEC2011, USA 2011; AJTEC2011-44042:1-6

[9] Сербін, С., Мостіпаненко, Г. (2006). Числове моделювання процесів горіння в експериментальному відсіку гібридної камери згоряння ГТД потужністю 25 МВт. Вісник Національного технічного університету «ХПІ». Серія: Енергетичні та теплотехнічні процеси й устаткування, (5), 59-67.

[10] Діасамідзе, Б.Т., Вілкул, С.В., \& Сербін, С.І. (2019). Теоретичні дослідження двопаливної низькоемісійної камери згоряння газотурбінного двигуна. Вісник Національного технічного університету «ХПI». Серія: Енергетичні та теплотехнічні прочеси й устаткування, (1), 27-33.

[11] Сербін С.І., Діасамідзе Б.Т. (2019). Дослідження впливу швидкості розпилювання рідкого палива на характеристики двопаливної газотурбінної камери згоряння. Збірник наукових праць НУК, (1).

[12] Serbin, S., Burunsuz, K. (2020). Numerical study of the parameters of a gas turbine combustion chamber with steam injection operating on distillate fuel. International Journal of Turbo \& Jet-Engines, 1 (ahead-of-print).

[13] Serbin, S., Diasamidze, B., \& Dzida, M. (2020). Investigations of the working process in a dual-fuel low-emission combustion chamber for an FPSO gas turbine engine. Polish Maritime Research.

[14] Cherednichenko, O., Serbin, S., \& Dzida, M. (2019). Investigation of the combustion processes in the gas turbine module of an FPSO operating on associated gas conversion products. Polish Maritime Research, 26(4), 149-156.

[15] El-Gohary, M.M. (2012). The future of natural gas as a fuel in marine gas turbine for LNG carriers. Proceedings of the Institution of Mechanical Engineers, Part M: Journal of Engineering for the Maritime Environment, 226(4), 371-377.

[16] Banawan, A.A., El Gohary, M.M., \& Sadek, I.S. (2010). Environmental and economical benefits of changing from marine diesel oil to natural-gas fuel for short-voyage high-power passenger ships. Proceedings of the Institution of Mechanical Engineers, Part M: Journal of Engineering for the Maritime Environment, 224(2), 103-113.

[17] El Gohary, M. M., \& Seddiek, I. S. (2013). Utilization of alternative marine fuels for gas turbine power plant onboard ships. International Journal of Naval Architecture and Ocean Engineering, 5(1), 21-32.

[18] Serbin, S., Kozlovskyi, A., \& Burunsuz, K. (2021). Influence of plasma-chemical products on process stability in a lowemission gas turbine combustion chamber. International Journal of Turbo \& Jet-Engines, 1 (ahead-of-print).

[19] Serbin, S.I. Modeling and Experimental Study of Operation Process in a Gas Turbine Combustor with a Plasma-Chemical Element. Combustion Science and Technology 1998; 139:137-158.

[20] Serbin, S.I., Kozlovskyi, A.V., Burunsuz, K.S. Investigations of non-stationary processes in low emissive gas turbine combustor with plasma assistance. IEEE Trans. Plasma Sci. 2016; 44(12):2960-2964. 